\title{
OPERATIONAL CONTROL SYSTEM OF CIVIL AICRAFT AIRBORNE EQUIPMENT AND SCIENTIFIC BASIS OF ITS FORMATION
}

\author{
S.V. KUZNETSOV ${ }^{\mathbf{1}}$ \\ ${ }^{1}$ Moscow State Technical University of Civil Aviation, Moscow, Russia
}

\begin{abstract}
The system of operational control (SOC) of civil aircraft (CA) airborne equipment incorporates onboard equipment, as an object of control, means and programs of operational control, maintenance personnel of an operating enterprise, carrying out procedures using control means and organizing processes of operational control for the specified objects using control programs. Quality of $\mathrm{A} / \mathrm{C}$ onboard equipment SOC becomes obvious in the process of operational control. Operational control is a set of processes for determining the technical condition (TC) of objects of control (OC) at the various operational stages: in flight, during operational maintenance (pre-flight and post-flight control), and periodic maintenance, after dismantling equipment from board. The process of determining OC TC of includes control, diagnostics, forecasting and recovery. The process of operational control is characterized by reliability of control - the property of TC control, which determines the extent of display objectivity as a result of monitoring the actual OC TC. Based on the SOC analysis as an object of research, the analysis of the problem of its forming and updating as well as the developed hierarchy of criteria for the effectiveness of interacting systems, the general problem will be formulated as follows: on a given set of parameters of onboard equipment SOC, let us determine the parameter values so that the system costs in the process of operational control reach minimum while performing all the required tasks and observing all the limitations for own parameters of the system as well as indicators of its technical efficiency.
\end{abstract}

Key words: operational control system, technical condition, reliability of control, airborne equipment, hierarchy of criteria.

\section{INTRODUCTION}

Onboard equipment SOC incorporates airborne equipment such as an object of control (OC), operational control means and programs, maintenance personnel of an operator executing the procedures applying control facilities and organizing the processes of operational control of the stated objects by means of control programs [1-2].

Control facilities are represented as the airborne control devices, ground-onboard and groundbased automated control aids incorporated with fulfilling operational control tasks for objects on board A/C such as: onboard complexes, functional systems, constructive-functional units, or Line Replaceable Units (LRU), constructive-functional modules, electrical and radio elements (ERE) [3-6].

The airborne control devices as a constituent part of onboard equipment are designed to control onboard equipment directly on board $\mathrm{A} / \mathrm{C}$ and implemented as integrated and self-contained control means. The integrated control facilities or built-in test equipment (BITE) as the OC constituent part, ensure control of onboard equipment functional systems on board $\mathrm{A} / \mathrm{C}$. They are represented as integral functional modules of control within LRU, as well as self-contained units of control [7-18].

Self-contained automated onboard means of control provide onboard equipment control on board A/C. Incorporated into airborne equipment as an independent component, they are implemented as functional systems control such as onboard maintenance systems (OMS).

The ground-onboard automated control facilities are intended to record operational capability and failures of equipment on board the $\mathrm{A} / \mathrm{C}$ using on-ground subsequent decryption of monitored information (a ground part). They are implemented as magnetic or solid-state facilities for recording parameters and systems of automatic data exchange with ground using decryption aids. On sophisticated aircraft integral systems of TC control are installed as constituent components of ground-onboard automated equipment.

On board A/C integral systems of TC control conduct continuous recording and processing the results of onboard equipment control in flight using onboard systems of control. The systems of auto- 
matic data exchange with ground execute continuous collection of data about the results of onboard equipment control using both airborne control devices and integral systems of TC control in flight with the subsequent transmission of this information over a radio channel to the ground. The ground part of ground-onboard automated control facilities make provision for data decryption stored on a magnetic or solid-state medium or for information obtaining from a radio signal.

On-ground control facilities are designed to monitor airborne equipment as directly on board $\mathrm{A} / \mathrm{C}$ as dismantled from board $\mathrm{A} / \mathrm{C}$ in the ground conditions. They are implemented as checkout and test facilities and ground-based automated equipment. Checkout and test facilities provide computeraided control of airborne equipment for functional systems, constructive-functional modules in the laboratory conditions and constitute the fixed and portable consoles. Ground-based computer-aided test equipment executes automated control of the airborne equipment for LRU, functional modules in the laboratory conditions and constitutes the fixed unified systems.

The programs of operational control determine the tasks and types, methods and algorithms, volumes and periodicity of airborne equipment operational control specified in the appropriate documentation applicable to $\mathrm{A} / \mathrm{C}$ and its systems maintenance and repair.

The objectives of airborne equipment operational control at the different stages are monitoring serviceability, operational capabilities, functionality, fault isolation, etc. The basic types of operational control are as follows: in-flight control, ground-based post-flight and pre-flight control, periodic maintenance, control of removed units from board $\mathrm{A} / \mathrm{C}$, etc. The variety of operational control methods is defined with the tasks and types: physical and parameter methods, passive and active, tolerance and test, etc. The algorithms of operational control are determined by the following tasks: algorithms of functionality control, operational capabilities, serviceability, fault isolation, etc. Volume and periodicity of operational control are specified with the methods of technical operation and the strategies of maintenance and repair.

In compliance with the programs and using operational control facilities maintenance personnel carry out the procedures and organize the processes of OC operational control that is aircraft hardware for the purpose of ensuring their efficient operation and the required flight safety.

Both flight officers of an airline and operator's engineering and technical staff are in charge of operational control. Flight officers perform a pre-flight inspection and monitor airborne control devices in flight. During line maintenance engineering and technical staff carry out post-flight control, fault isolation on board A/C. During periodic maintenance engineering and technical staff test functionality and serviceability on board A/C. Maintenance personnel of a laboratory check workshop test and locate faults in removed units with accuracy within integral functional modules or ERE. Engineering and technical personnel of maintenance operations centers organize the processes, accumulate and generalize operational control experience.

\section{STRUCTURE OF AIRBORNE EQUIPMENT OPERATIONAL CONTROL PROCESS AND RELIABILITY OF CONTROL}

Quality of A/C airborne equipment SOC becomes evident in the process of operational control. Operational control is a set of the processes to determine OC TC at the different stages of operation: in flight, during line maintenance (pre-flight and post-flight tests) and periodic maintenance, after equipment dismantling from board. The process to determine OC TC comprises control, diagnostics, forecasting and recovery.

The process of OC TC determines the technical condition type as a variety of affected OC characteristics during operation characterized at a certain point with the criteria established with the technical documentation for this object. Control is divided into control of serviceability, operational capabilities and functioning depending on TC type determined during control. 
Diagnostics of OC TC under diagnostics determines its faulty or inoperative condition based on the variety of faulty and inoperative conditions. Depending on the degree of troubleshooting, diagnostics of airborne equipment is distinguished as the diagnosis within the accuracy of the functional system, unit, constructive-functional module or ERE.

Forecasting of OC TC under forecasting determines its condition at a certain point or the time interval during which actual OC TC is maintained.

Recovery of OC TC under recovery determines its condition during the previous time interval.

Operational capabilities control of onboard complexes and functional systems of flight and navigation equipment as well as diagnostics within the accuracy of airborne equipment functional systems are executed during in-flight control. During post-flight and pre-flight control monitoring airborne equipment functional systems, complexes functioning as well as LRU diagnostics are executed. During periodic maintenance control of functional systems and complexes serviceability as well as diagnostics within the accuracy of the airborne equipment unit are executed. Control of onboard equipment dismantled units' serviceability, diagnostics within the accuracy of LRU or ERE, forecasting and recovery of the functional systems and airborne equipment units are executed.

The process of operational control is characterized with control reliability - the control characteristic of OC TC determining the degree of display objectivity as a result of control of OC TC actual type. In accordance with the various types of operational control it is reasonable to define the basic characteristic of control.

Reliability of in-flight control is the control characteristic for TC of airborne equipment functional systems and complexes by means of airborne control devices. Reliability of post-flight and preflight tests is the control characteristic for TC of airborne equipment functional systems and onboard complexes using onboard and ground control facilities. Reliability of dismantled equipment tests is the control characteristic for LRU TC, dismantled units, constructive-functional modules and ERE of onboard equipment by means of ground control facilities.

Reliability of diagnostics is the characteristic to determine OC TC under diagnosis that allows us to specify the degree of display objectivity as a result of diagnostics of the actual type of OC TC.

Reliability of in-flight diagnostics is the diagnosis characteristic of airborne equipment functional systems and complexes TC by means of airborne control devices.

Reliability of post-flight and pre-flight diagnostics is the diagnosis characteristic of airborne equipment functional systems and complexes TC by means of ground, onboard control facilities.

Reliability of dismantled equipment diagnostics is the diagnosis characteristic of constructivefunctional modules and ERE, dismantled units, LRU TC by means of ground control facilities.

As a rule, diagnostics on board $\mathrm{A} / \mathrm{C}$ is conducted within the accuracy of LRU, whereas on the ground it is implemented within the accuracy of constructive-functional modules, more rarely within ERE accuracy.

\section{ANALYSIS OF THE PROBLEM FOR FORMING AND UPGRADING THE SYSTEM OF AIRBORNE EQUIPMENT OPERATIONAL CONTROL}

Let us define the role and place of the system of operational control (SOC) within the technical operation system. Onboard equipment SOC is subordinated to the technical operation system. Its quality is determined with the performance function to meet the requirements of the airborne equipment technical operation system with maximum economic efficiency under the limitations for the required levels of onboard equipment control reliability. SOC effectiveness becomes obvious in the process of onboard equipment operational control.

Thus, onboard equipment SOC forming a constituent part of the operation system has all the features inherent for sophisticated technical systems, that is: a hierarchical structure and obedience of purposes, interrelationship of components, handling while functioning. It allows us to make a conclusion that 
forming and upgrading SOC should be conducted on the basis of the comprehensive system analysis considering all the processes happening within the system by means of the up-to-date mathematical methods.

In accordance with the hierarchy of purposes for the aircraft transport system functioning and interrelation of the purposes for the systems of lower level hierarchy: the aircraft operation system, airborne equipment operational control and technical operation systems, the major problem of forming and upgrading airborne equipment SOC is maintaining the required level of control reliability that tests the level of equipment reliability, consequently, the aircraft reliability level and eventually the flight safety level.

In compliance with the requirements of airworthiness, whatever airborne equipment failures should not cause an abnormal situation that could be worse than deterioration of flight safety.

Failures that are impossible to reveal during the process of operational control, specified by low control reliability, are the causes of a prerequisite to an aviation accident through the fault of onboard equipment SOC. Similar failures reduce substantially reliability of onboard equipment functioning, decrease the efficiency indicators of the onboard equipment technical operation system, aircraft technical operation system and aircraft transport system, affect flight safety.

The following key factor of forming and upgrading onboard equipment SOC is assurance of the required level of flights regularity. Regularity of flight operations incorporates the conceptions of departure and performing flights regularity. Disruption of regularity is caused by in-flight failures that affect performance capabilities or deteriorate efficiency of $\mathrm{A} / \mathrm{C}$ systems functioning. In fact, all these failures are attributed to prerequisites to an aviation accident. The causes of disruption of performing flights regularity through the fault of airborne equipment SOC are not revealed airborne equipment failures during operational control due to low control reliability.

Disruption of departure regularity is considered while determining flight delays due to late $\mathrm{A} / \mathrm{C}$ arrival. The major reason for flight delays in the event of airborne equipment failures is complexity of troubleshooting at a particular point. Recovery time is comprised of fault isolating time, fault location and its subsequent repair in the conditions provided by airborne equipment SOC. Low control reliability of control facilities impacts considerably the efficiency indicators of regular departures.

The following key factor of forming and upgrading airborne equipment SOC is maximum economic efficiency. Economic efficiency of the technical operation process is specified by the value of operational costs necessary to maintain one-hour flight.

A considerable item of operational costs in onboard equipment SOC is costs to purchase and service multiproduct sets of test and checkout equipment that contain up to hundreds of items.

And eventually, another considerable item of operational costs is costs to purchase multiproduct sets of spare parts for onboard equipment units, volume of which substantially exceeds real demand due to low operational control reliability.

The main cause of the negative effect on the efficiency indicators of airborne equipment SOC, aircraft transport and technical operation systems is the fact that forming SOC for the operational aircraft fleet has been always funded far inferior to need without an analysis of the processes of operational control, mutual considering the characteristics of system constitutive parts. Unfortunately, the similar approach has remained partially unchanged while forming SOC for a new generation of civil aircraft SSJ-100 and MC21. However, the research results allowed us to improve, to the particular extent, the procedure of airborne equipment SOC formation due to the system analysis and introduction of the synthesis elements.

\section{STRUCTURE OF THE AIRBORNE EQUIPMENT OPERATIONAL CONTROL SYSTEM AND THE PROBLEM OF ITS FORMING AND UPGRADING}

The structure of airborne equipment SOC for modern and promising aircraft is given in Figure 1.

The onboard equipment complex comprises $n$ functional systems. Each one has its own onboard control facilities. The functional systems include $\mathrm{m}$ LRU that, as a rule, are equipped with BITE as well. LRU incorporate 1 constructive-functional modules. Each module consists of $\mathrm{k}$ ERE. 
The results of built-in test enter OMS that activates BITE and executes on-board control during post-flight and pre-flight test. The results of post-flight and pre-flight tests are stored in the onboard integral system of TC control that can initiate a thorough onboard equipment test if necessary applying OMS. Additionally, the integrated system of TC control stores parameter information in its memory that, coupled with in-flight, post-flight and pre-flight test results, enters the ground part of the integral system of TC control for decryption and taking a decision.

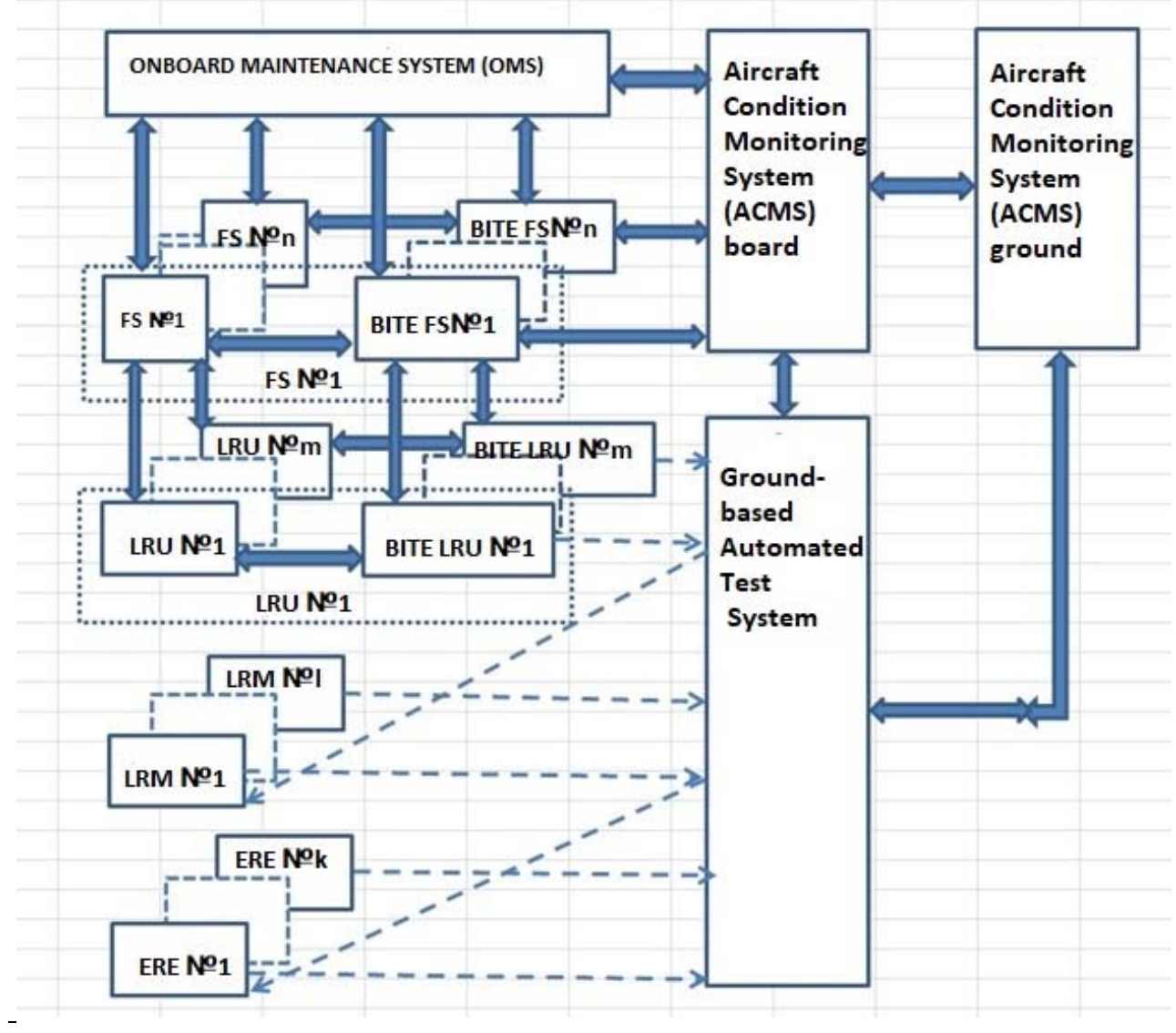

Fig. 1. The structure of the operational control system of airborne equipment

Dismantled from board LRU enter ground-based computer-aided equipment to a laboratory where they undergo monitoring, diagnosis, and possibly, recovery by replacing structural-functional modules and ERE.

Thus, circulation of onboard equipment components and information about the components TC, generated by the onboard control facilities, OMS and integral systems of TC control occurs.

Onboard control facilities solve the following tasks:

- perform instrumental and information control;

- perform continuous automatic monitoring of own performance capabilities in flight and issue information about its condition in the matrix-condition of computing systems data-word. In the event of failure, words-conditions of failures are formed and issued;

- receive an external control input (command) of "Control" mode and initiate extensive (ground) control;

- store and issue information about revealed failures of units to OMS and integrated systems of TC control;

- continue proper functioning after being de-energized;

- assess reliability of input information from the sensor systems; 
- form words-conditions and issue them to OMS and integral systems of TC control storing words-conditions in the memory until the completion of the flight.

OMS and integral system of TC control implement the following functions:

- performing pre-flight and post-flight tests procedures of onboard equipment;

- maintenance of onboard equipment by maintenance personnel;

- obtaining data about failures and malfunctions of onboard equipment hardware from OMS;

- fault isolating of onboard equipment within the accuracy of LRU with the subsequent data display about a mode of failure;

- data storage of malfunctions and failures;

- assignment of "Control" mode and its sub-modes to the functional onboard equipment systems forming the integral input such as "ready", "not ready";

- temporary referencing of equipment failures to motion variables and aircraft attitude;

- filing failure data and recording parameters required to investigate accidents, also to determine onboard equipment TC and forecast a pre-failure condition of LRU based on values of integral parameters.

On-ground automated control aids implement the following functions:

- operational check of performance capabilities while conducting scheduled and repair work, storage, adjustment, when obtaining new units from plants-manufacturers as well;

- fault isolating within the accuracy of constructive-functional modules or ERE in compliance with the maintenance strategy;

- adjusting and parameter setting of units after replacing a constructive-functional module or ERE;

- functioning of local area computer networks according to the prescribed protocols;

- filing control results;

- issuing test results in the convenient format for an operator and further processing;

- issuing the required reference information during adjustment and alignment work.

In-flight in the event of failure the automatic system of data exchange transmits a troubleshooting code to the ground using radio communication aids. After decryption of the malfunction code prior to $\mathrm{A} / \mathrm{C}$ arrival, maintenance personnel prepare the required units for replacement, tooling, consumables, expendable materials and the algorithm of troubleshooting.

The disadvantage of the SOC structure is that BITE, ground-based computer-aided equipment, ground-onboard automated control facilities as well as onboard operational control systems are developed by various manufacturers and enterprises. Each of them contributes their own specifics into the SOC structure. Due to absence of the unified concept of utilizing these aids during operation, there are no reasonable standards to their operational characteristics. Therefore, the main problem of forming and upgrading onboard equipment SOC is minimizing operating costs during operational control by reassigning the requirements to reliability of various types of control applying different test facilities. With regard to the above mentioned, flight safety requirements should be fully accomplished.

\section{HIERARCHY OF EFFICIENCY CRITERIA FOR ONBOARD EQUIPMENT OPERATIONAL CONTROL SYSTEM AND INTERRELATED SYSTEMS}

In accordance with the hierarchy of functioning purposes for $\mathrm{A} / \mathrm{C}$ aviation-transport system, $\mathrm{A} / \mathrm{C}$ technical operation system, onboard equipment operation system and SOC let us build the hierarchy of efficiency criteria for these systems. For this purpose it is necessary to formalize the system-solvable problems characterizing their parameters and efficiency indicators as well as relevant processes.

Let us consider the efficiency criterion for the system of the third level hierarchy of SOC solving the set $\Omega_{\mathrm{C} Э \mathrm{KK}}^{\mathrm{EO}}$. Onboard equipment SOC as the system of the second level hierarchy introduces the set $\Omega_{\mathrm{C} Э \mathrm{~K}}^{\mathrm{EO}}$ for onboard equipment SOC solution for $\left(\Omega_{\mathrm{C} Э \mathrm{~K}}^{\mathrm{5O}}\right)^{*} \in\left(\Omega_{\mathrm{CT}}^{\mathrm{БO}}\right)^{*}$. 
Onboard equipment SOC has the set of parameters $\Gamma_{\mathrm{C} Э \mathrm{~K}}^{\mathrm{EO}}=\left\{\gamma_{\mathrm{C} \ni \kappa}^{\mathrm{GO}}(\mathrm{j})\right\}$ defined with its structure, relationships, resources and characteristics. As all the structures and relationships are conservative, the resources are limited, but characteristics cannot exceed the certain ultimate values, the set $\Gamma_{\mathrm{C} \ni \mathrm{K}}^{\mathrm{EO}}$ is within the boundaries of the set $\Gamma_{\mathrm{C} Э \mathrm{EK}}^{\mathrm{EO}}=\left\{\gamma_{\mathrm{C} Э \mathrm{~K}}^{\mathrm{EO}}(\mathrm{j})\right\}$, that is $\gamma_{\mathrm{C} Э \mathrm{~K}}^{\mathrm{EO}}(\mathrm{j}) \leq\left[\gamma_{\mathrm{C} Э \mathrm{KK}}^{\mathrm{E}}(j)\right]^{*}$ to all $j$.

The process of onboard equipment SOC $\xi_{\ni К}^{\mathrm{DO}}\left(\mathrm{t}, \Gamma_{\mathrm{C} \ni \mathrm{K}}^{\mathrm{EO}}\right)$ is both the constituent part of the process of onboard equipment operation $\xi_{\mathrm{T}}^{\mathrm{БO}}$ and the function time of $t$ as well as the set of parameters $\Gamma_{\mathrm{C} Э \mathrm{~K}}^{\mathrm{БO}}$.

Economic efficiency of onboard equipment SOC is characterized with operational costs $\mathrm{C}_{\mathrm{C} Э \mathrm{~K}}^{\mathrm{O}}$, determined in the process of operational control $\mathrm{C}_{\mathrm{CЭK}}^{\mathrm{EO}}\left[\xi_{\ni К}^{\mathrm{GO}}\left(\mathrm{t}, \Gamma_{\mathrm{C} Э \mathrm{~K}}^{\mathrm{DO}}\right)\right]$.

Technical efficiency of onboard equipment SOC is characterized with the set of values $\mathrm{R}_{\mathrm{C} Э \mathrm{~K}}^{\mathrm{БO}}=\left\{r_{\mathrm{C} Э \mathrm{~K}}^{\mathrm{БO}}(l)\right\}$, considering each indicator $\mathrm{r}_{\mathrm{CЭК}}^{\mathrm{БO}}(l)=r_{\mathrm{C} Э \mathrm{~K}}^{\mathrm{БO}}\left(\mathrm{t}, \Gamma_{\mathrm{C} Э \mathrm{~K}}^{\mathrm{БO}}\right)$ as the function of time $\boldsymbol{t}$ and the set of parameters $\Gamma_{\mathrm{C} Э \mathrm{~K}}^{\mathrm{EO}}$. Onboard equipment SOC as the system for the hierarchy of higher level introduces the required values of technical efficiency indicators set for $\operatorname{SOC}\left(R_{\mathrm{CЭK}}^{\mathrm{EO}}\right)^{*}=\left\{\left[r_{\mathrm{C} Э \mathrm{~K}}^{\mathrm{EO}}(l)\right]^{*}\right\}$.

The criterion of onboard equipment SOC efficiency is minimum of operational costs on the pre-assigned set of the system parameters during operational control while solving all the problems required by onboard equipment SOC and observing all the limitations as for SOC own parameters as for the technical efficiency indicators defined by onboard equipment SOC.

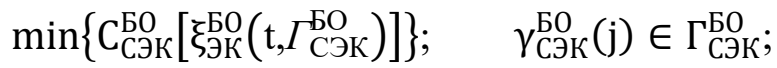

$$
\begin{aligned}
& \left(\Omega_{\mathrm{CЭK}}^{\text {БО }}\right)^{*}-\Omega_{\text {СЭК }}^{\text {БО }}=\varnothing ; \quad\left(\Omega_{\text {СЭК }}^{\text {БО }}\right)^{*} \in\left(\Omega_{\text {СТЭ }}^{\text {БО }}\right)^{*} \text {; }
\end{aligned}
$$

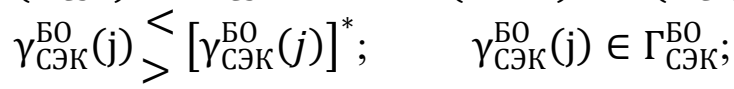

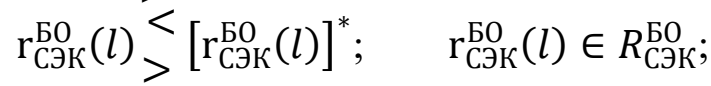

$$
\begin{aligned}
& \left(R_{\text {СЭК }}^{\text {БО }}\right)^{*} \in\left(R_{\text {СТЭ}}^{\text {БО }}\right)^{*} \text {. }
\end{aligned}
$$

\section{CONCLUSIONS}

Let us formulate a general problem on the basis of SOC analysis as an object of research, the analysis of problem for its forming and updating as well as the developed hierarchy of the efficiency criteria of interacting with SOC systems as follows.

On the given set of onboard equipment SOC let us define the parameter values so that the system costs come to minimum during the process of operational control while performing all the required tasks and limitations for the own system parameters and its technical efficiency indicators.

For the solution of the general problem it is necessary to solve sequentially the following intermediates:

- choose and lay a foundation for the parameters and the basic indicators of onboard equipment SOC efficiency inseparably interrelated with the basic efficiency indicators for the systems of the higher level hierarchy, in particular, the technical operation system;

- develop mathematical models for the processes of onboard equipment operational control for the different levels of extension (dismantled unit - functional system - complex);

- develop mathematical models for optimization of operational control processes;

- execute mathematical modeling for the operational control processes, develop SOC software and assess reliability of control and diagnostics of onboard equipment;

- assess the expected technical and economic effect as reduction of operational costs while using SOC. 
Probability theory (Bayesian approach to random variables, Markov chains), mathematical statistics (determination of random variables for moments and designing a statistical experiment using simulation modeling) serve as the theoretical basis to solve the given problems.

The conducted research establishes a theoretical basis for forming and upgrading onboard equipment SOC.

\section{REFERENCES}

1. Kuznetsov, S.V. (2017). Mathematical models of processes and systems of technical operation for onboard complexes and functional systems of avionics. Civil Aviation High Technologies, vol. 20, no. 1, pp. 132-140. (in Russian)

2. Kuznetsov, S.V. (2017). Avionics technical operation system and scientific basis for its formation. Civil Aviation High Technologies, vol. 20, no. 6, pp. 15-24. DOI: 10.26467/2079-06192017-20-6-15-24 (in Russian)

3. Fedosov, Ye.A., Kos'yanchuk, V.V. and Sel'vesyuk, N.I. (2015). Integrirovannaya modulnaya avionika [Integrated modular avionics]. Radioelektronnyye tekhnologii, no. 1, pp. 66-71. (in Russian)

4. Kulabukhov, V.S. (2015). Federative-integrated distributed modular avionic. Aerospace Instrument-Making, no. 12, pp. 11-31. (in Russian)

5. Fedosov, Ye.A. (2017). Osnovnyye napravleniya formirovaniya nauchno-tekhnicheskogo zadela $v$ oblasti bortovogo oborudovaniya perspektivnykh vozdushnykh sudov [The main directions of the scientific and technical reserve formation in the field of the prospective aircraft on-board equipment]. Perspektivnyye napravleniya razvitiya bortovogo oborudovaniya grazhdanskikh vozdushnykh sudov: materialy dokladov 4-y Mezhdunarodnoy konferentsii [Prospective Development Directions for the Civil Aircraft On-Board Equipment: Proceedings of the $4^{\text {th }}$ International Conference]. Moscow: GosNII AS, pp. 6-14. (in Russian)

6. Polyakov, V.B., Neretin, Ye.S., Ivanov, A.S., Budkov, A.S., Dyachenko, S.A. and Dudkin, S.O. (2018). Architecture of prospective onboard equipment control complexes. Trudy MAI, issue 100, 21 p. Available at: http:/trudymai.ru/upload/iblock/0e5/Polyakov_Neretin_Ivanov_ Budkov_Dyachenko_Dudkin_rus.pdf?lang=ru\&issue=100 (accessed: 26.03.2021). (in Russian)

7. Das, S. (2015). An efficient way to enable prognostics in an onboard system. 2015 IEEE Aerospace Conference, pp. 1-7. DOI: 10.1109/AERO.2015.7118976

8. Prisacaru, A., Gromala, P.J., Jeronimo, M.B., Bongtae, Han and Zhang, G.Q. (2017). Prognostics and health monitoring of electronic system: A review. 2017 18th International Conference on Thermal, Mechanical and Multi-Physics Simulation and Experiments in Microelectronics and Microsystems (EuroSimE), pp. 1-11. DOI: 10.1109/EuroSimE.2017.7926248

9. Soltanipour, N., Rahrovani, S., Martinsson, J. and Westlund, R. (2020). Chassis hardware fault diagnostics with hidden markov model based clustering. 2020 IEEE 23rd International Conference on Intelligent Transportation Systems (ITSC), pp. 1-6. DOI: 10.1109/ITSC45102.2020. 9294468

10. Cao, J., Fu, X., Fang, X., Hu, Y., Zhou, G. and Jia, H. (2018). Bayesian network based diagnostics technique for civil aircraft. 2018 IEEE CSAA Guidance, Navigation and Control Conference (CGNCC), pp. 1-7. DOI: 10.1109/GNCC42960.2018.9019212

11. Korvesis, P., Besseau, S. and Vazirgiannis, M. (2018). Predictive maintenance in aviation: failure prediction from post-flight reports. 2018 IEEE 34th International Conference on Data Engineering (ICDE), pp. 1414-1422. DOI: 10.1109/ICDE.2018.00160

12. Zeitler, A. (2019). Challenges of certification and integration of new hardware into legacy avionics architectures. 2019 IEEE/AIAA 38th Digital Avionics Systems Conference (DASC), pp. 1-5. DOI: 10.1109/DASC43569.2019.9081621 
13. Annighoefer, B., Halle, M., Schweiger, A., Reich, M., Watkins, C., VanderLeest, S.H., Harwarth, S. and Deiber, P. (2019). Challenges and ways forward for avionics platforms and their development in 2019. 2019 IEEE/AIAA 38th Digital Avionics Systems Conference (DASC), pp. 1-10. DOI: 10.1109/DASC43569.2019.9081794

14. Wang, M., Xiao, G., Liu, X. and Wang, G. (2019). Integrated modular avionics system design based on formal dynamic organization. 2019 IEEE/AIAA 38th Digital Avionics Systems Conference (DASC), pp. 1-8. DOI: 10.1109/DASC43569.2019.9081755

15. Valdivia de Matos, H.L. (2018). Model-based specification of integrated modular avionics systems using object-process methodology. 2018 IEEE/AIAA 37th Digital Avionics Systems Conference (DASC), pp. 1-8. DOI: 10.1109/DASC.2018.8569855

16. Cevher, S., Mumcu, A., Caglan, A., Kurt, E., Peker, M.K., Hokelek, I. and Altun, S. (2018). A fault tolerant software defined networking architecture for integrated modular avionics. 2018 IEEE/AIAA 37th Digital Avionics Systems Conference (DASC), pp. 1-9. DOI: 10.1109/DASC. 2018.8569681

17. Luis, P., Gaëlle, L., Yue, M. and Chantal, R. (2018). Knowledge discovery for avionics maintenance support. 2018 IEEE/AIAA 37th Digital Avionics Systems Conference (DASC), pp. 1-8. DOI: $10.1109 /$ DASC.2018.8569856

18. Wu, Y., XIAO, G., Wang, G., He, F., Dai, Z. and Wang, Y. (2018). Research on safety analysis method of functional integrated avionics systems. 2018 IEEE/AIAA 37th Digital Avionics Systems Conference (DASC), pp. 1-10. DOI: 10.1109/DASC.2018.8569355

\title{
INFORMATION ABOUT THE AUTHOR
}

Sergey V. Kuznetsov, Doctor of Engineering Sciences, Professor, Head of Aircraft Electrical Systems and Avionics Technical Operation Chair, Moscow State Technical University of Civil Aviation,s.kuznetsov@mstuca.aero.

\section{СИСТЕМА ЭКСПЛУАТАЦИОННОГО КОНТРОЛЯ БОРТОВОГО ОБОРУДОВАНИЯ ВОЗДУШНЫХ СУДОВ ГРАЖДАНСКОЙ АВИАЦИИ И НАУЧНЫЕ ОСНОВЫ ЕЕ ФОРМИРОВАНИЯ}

\author{
С.В. Кузнецов ${ }^{1}$ \\ ${ }^{1}$ Московский государственный технический университет гражданской авиациии, \\ 2. Москва, Россия
}

Система эксплуатационного контроля (СЭК) бортового оборудования воздушных судов (ВС) гражданской авиации (ГА) объединяет бортовое оборудование как объект контроля, средства и программы эксплуатационного контроля, инженерно-технический состав эксплуатационного предприятия, осуществляющий с помощью средств контроля процедуры и организующий с помощью программ контроля процессы эксплуатационного контроля указанных объектов. Качество системы эксплуатационного контроля бортового оборудования ВС проявляется в процессе эксплуатационного контроля. Эксплуатационный контроль - это совокупность процессов определения технического состояния объектов контроля (ОК) на различных этапах эксплуатации: в полете, при оперативном ТО (предполетный и послеполетный контроль), при периодическом ТО, после демонтажа оборудования с борта. Процесс определения технического состояния (ТС) ОК включает контроль, диагностирование, прогнозирование и воспроизведение. Процесс эксплуатационного контроля характеризуется достоверностью контроля - свойством контроля ТС ОК, определяющим степень объективности отображения в результате контроля действительного вида технического состояния ОК. На основании анализа СЭК как объекта исследования, анализа проблемы ее формирования и совершенствования, а также разработанной иерархии критериев эффективности взаимодействующих с ней систем общую задачу сформулируем следующим образом. На заданном множестве параметров СЭК бортового оборудования определить значения параметров такие, чтобы затраты системы в процессе эксплуатационного контроля достигали минимума при выполнении всех 
требуемых задач и соблюдении всех ограничений на собственные параметры системы и показатели ее технической эффективности.

Ключевые слова: система эксплуатационного контроля, техническое состояние, достоверность контроля, бортовое оборудование, иерархия критериев.

\section{СПИСОК ЛИТЕРАТУРЫ}

1. Кузнецов С.В. Математические модели процессов и систем технической эксплуатации бортовых комплексов и функциональных систем авионики // Научный Вестник МГТУ ГА. 2017. T. 20, № 1. С. 132-140.

2. Кузнецов С.В. Система технической эксплуатации авионики и научные основы ее формирования // Научный Вестник МГТУ ГА. 2017. Т. 20, № 6. С. 15-24. DOI: 10.26467/20790619-2017-20-6-15-24

3. Федосов Е.А., Косьянчук В.В., Сельвесюк Н.И. Интегрированная модульная авионика // Радиоэлектронные технологии. 2015. № 1. С. 66-71.

4. Кулабухов В.С. Федеративно-интегрированная распределенная модульная авионика // Авиакосмическое приборостроение. 2015. № 12. С. 11-31.

5. Федосов Е.А. Основные направления формирования научно-технического задела в области бортового оборудования перспективных воздушных судов // Перспективные направления развития бортового оборудования гражданских воздушных судов: материалы докладов 4-й Международной конференции. Москва, Жуковский, 20 июля 2017 г. Дом ученых ФГУП «ЦАГИ». М.: ГосНИИ АС, 2017. С. 6-14.

6. Поляков В.Б. Архитектура перспективных комплексов управления бортовым оборудованием / В.Б. Поляков, Е.С. Неретин, А.С. Иванов, А.С. Будков, С.А. Дяченко, С.О. Дудкин [Электронный ресурс] // Труды МАИ. 2018. Вып. 100. 21 c. URL: http:/trudymai.ru/ upload/iblock/0e5/Polyakov_Neretin_Ivanov_Budkov_Dyachenko_Dudkin_rus.pdf?lang=ru\&issue=100 (дата обращения: 26.03.2021).

7. Das S. An efficient way to enable prognostics in an onboard system // IEEE Aerospace Conference, 2015. Pp. 1-7. DOI: 10.1109/AERO.2015.7118976

8. Prisacaru A. Prognostics and health monitoring of electronic system: A review / A. Prisacaru, P.J. Gromala, M.B. Jeronimo, Bongtae Han, G.Q. Zhang // 2017 18th International Conference on Thermal, Mechanical and Multi-Physics Simulation and Experiments in Microelectronics and Microsystems (EuroSimE), 2017. Pp. 1-11. DOI: 10.1109/EuroSimE.2017.7926248

9. Soltanipour N. Chassis hardware fault diagnostics with hidden markov model based clustering / N. Soltanipour, S. Rahrovani, J. Martinsson, R. Westlund // 2020 IEEE 23rd International Conference on Intelligent Transportation Systems (ITSC), 2020. Pp. 1-6. DOI: 10.1109/ITSC45102. 2020.9294468

10. Cao J. Bayesian network based diagnostics technique for civil aircraft / J. Cao, X. Fu, X. Fang, Y. Hu, G. Zhou, H. Jia // 2018 IEEE CSAA Guidance, Navigation and Control Conference (CGNCC), 2018. Pp. 1-7. DOI: 10.1109/GNCC42960.2018.9019212

11. Korvesis P., Besseau S., Vazirgiannis M. Predictive maintenance in aviation: failure prediction from post-flight reports // 2018 IEEE 34th International Conference on Data Engineering (ICDE), 2018. Pp. 1414-1422. DOI: 10.1109/ICDE.2018.00160

12. Zeitler A. Challenges of certification and integration of new hardware into legacy avionics architectures // 2019 IEEE/AIAA 38th Digital Avionics Systems Conference (DASC), 2019. Pp. 1-5. DOI: $10.1109 / \mathrm{DASC} 43569.2019 .9081621$

13. Annighoefer B. Challenges and ways forward for avionics platforms and their development in 2019 / B. Annighoefer, M. Halle, A. Schweiger, M. Reich, C. Watkins, S.H. VanderLeest, 
S. Harwarth, P. Deiber // 2019 IEEE/AIAA 38th Digital Avionics Systems Conference (DASC), 2019. Pp. 1-10. DOI: 10.1109/DASC43569.2019.9081794

14. Wang M. Integrated modular avionics system design based on formal dynamic organization / M. Wang, G. Xiao, X. Liu, G. Wang // 2019 IEEE/AIAA 38th Digital Avionics Systems Conference (DASC), 2019. Pp. 1-8. DOI: 10.1109/DASC43569.2019.9081755

15. Valdivia de Matos H.L. Model-based specification of integrated modular avionics systems using object-process methodology // 2018 IEEE/AIAA 37th Digital Avionics Systems Conference (DASC), 2018. Pp. 1-8. DOI: 10.1109/DASC.2018.8569855

16. Cevher S. A fault tolerant software defined networking architecture for integrated modular avionics / S. Cevher, A. Mumcu, A. Caglan, E. Kurt, M.K. Peker, I. Hokelek, S. Altun // 2018 IEEE/AIAA 37th Digital Avionics Systems Conference (DASC), 2018. Pp. 1-9. DOI: 10.1109/ DASC.2018.8569681

17. Luis P. Knowledge discovery for avionics maintenance support / P. Luis, L. Gaëlle, M. Yue, R. Chantal // 2018 IEEE/AIAA 37th Digital Avionics Systems Conference (DASC), 2018. Pp. 1-8. DOI: 10.1109/DASC.2018.8569856

18. Wu Y. Research on safety analysis method of functional integrated avionics systems / Y. Wu, G. XIAO, G. Wang, F. He, Z. Dai, Y. Wang // 2018 IEEE/AIAA 37th Digital Avionics Systems Conference (DASC), 2018. Pp. 1-10. DOI: 10.1109/DASC.2018.8569355

\section{СВЕДЕНИЯ ОБ АВТОРЕ}

Кузнецов Сергей Викторович, профессор, доктор технических наук, заведующий кафедрой технической эксплуатации авиационных электросистем и пилотажно-навигационных комплексов МГТУ ГА, s.kuznetsov@mstuca.aero.

$\begin{array}{llll}\text { Поступила в редакцию } & 25.02 .2021 & \text { Received } & 25.02 .2021 \\ \text { Принята в печать } & 20.05 .2021 & \text { Accepted for publication } & 20.05 .2021\end{array}$

